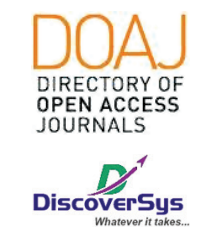

Published by DiscoverSys

\section{Faktor risiko diare pada anak usia 1-12 tahun di wilayah kerja Puskesmas II Denpasar Barat, Bali, Indonesia}

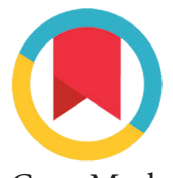

CrossMark

\author{
I Putu Oka Kresna Jayadi, ${ }^{1}$ I Made Adi Narendranatha Komara, ${ }^{1 *}$ \\ Made Aditya Artha Nugraha, ${ }^{1}$ I Dewa Gede Agung Suta Ariwangsa, ${ }^{1}$ \\ Putu Triyasa, ${ }^{1}$ I Nengah Kapti ${ }^{2}$
}

\title{
ABSTRACT
}

Background: Diarrhea is a public health problem, with high morbidity and the potential to cause death. A survey conducted from 2000-2010 in Indonesia shows that the incidence of diarrhea is increasing. In Denpasar, diarrhea is one of the top 10 diseases found in Puskesmas. This study aims to determine the risk factors for diarrhea in children aged 1-12 years in the working area of Puskesmas II West Denpasar, Bali, Indonesia.

Methods: This study used a case-control analytical method to 86 respondents, which involved 43 children aged $1-12$ years with diarrhea for the case and 43 children without diarrhea as a control. This research was conducted from October to December 2017, using consecutive techniques. Data were analyzed using SPSS version 20 for Windows.

Results: The results of this study indicate that most of the respondents aged 1-5 years $(69.76 \%)$ compared to those aged $>5-12$ years
(30.24\%). The percentage of female sex was greater both in the $1-5$ years age group $(37.20 \%)$ and $>5-12$ years $(18.60 \% \%)$ than men. The percentage of bottled water consumption was higher in the control group (79.10\%) than in cases (55.80\%). There was a significant relationship between diarrhea and environment and hygiene $(0 \mathrm{R}=$ 5,247; 95\% Cl: 2,050-13,590; $p=0,000$;), hand washing behavior $(\mathrm{OR}=4,483 ; 95 \% \mathrm{Cl}: 1,732-12,132 ; \mathrm{p}=0.002)$, and food (OR=3,529; $95 \%$ Cl: $1,445-8,619 ; p=0.005 ;)$. However, there was no significant relationship between diarrhea and drinking water sources $(0 R=$ 2.246; 95\% (l: 0.917-5.504; $p=0.074$;).

Conclusion: Environmental and hygiene variables, handwashing behavior, and food have a significant relationship with the incidence of diarrhea in children aged 1-12 years in the working area of Puskesmas II Denpasar Barat, Bali, Indonesia.

Keywords: Diarrhea, Children, Risk Factors

Cite This Article: Jayadi, I.P.O.K., Komara, I.M.A.N., Nugraha, M.A.A., Ariwangsa, I.D.G.A.S., Triyasa, P., Kapti, I.N. 2020. Faktor risiko diare pada anak usia 1-12 tahun di wilayah kerja Puskesmas II Denpasar Barat, Bali, Indonesia. Intisari Sains Medis 11(2): 711-716. D0I: 10.15562/ism. v11i2.673

\section{ABSTRAK}

'Departemen IImu Kesehatan Anak, Fakultas Kedokteran dan IImu Kesehatan, Universitas Warmadewa, Rumah Sakit Umum Daerah Sanjiwani, Bali, Indonesia ${ }^{2}$ Dosen Bagian Parasitologi, Fakultas Kedokteran dan IImu Kesehatan, Universitas Warmadewa, Bali, Indonesia

\section{*Korespondensi:}

I Made Adi Narendranatha Komara, Departemen IImu Kesehatan Anak, Fakultas Kedokteran dan IImu Kesehatan, Universitas Warmadewa, Rumah Sakit Umum Daerah Sanjiwani, Bali, Indonesia; adinarendra40@gmail.com
Latar Belakang: Diare merupakan salah satu masalah kesehatan masyarakat, dengan angka kesakitan tinggi dan berpotensi menyebabkan kematian. Survei yang dilakukan dari tahun 2000-2010 di Indonesia terlihat kecendrungan insidens diare meningkat. Di Kota Denpasar diare masuk 10 besar penyakit yang dijumpai di Puskesmas. Penelitian ini bertujuan untuk mengetahui faktor risiko diare pada anak usia 1-12 tahun di wilayah kerja Puskesmas II Denpasar Barat, Bali, Indonesia.

Metode: Penelitian ini menggunakan metode analitik case-control terhadap 86 responden dimana melibatkan 43 anak berusia 112 tahun dengan diare untuk case dan 43 anak tidak menderita diare sebagai control. Penelitian ini dilaksanakan pada bulan Oktober sampai dengan Desember 2017 dengan menggunakan teknik konsekutif. Data dianalisis dengan SPSS versi 20 untuk Windows.

Hasil: Hasil penelitian ini menunjukkan bahwa sebagian besar responden berusia $1-5$ tahun $(69,76 \%)$ dibandingkan usia $>5-12$ tahun
$(30,24 \%)$. Jenis kelamin perempuan secara persentase lebih besar baik pada kelompok usia 1-5 tahun $(37,20 \%)$ dan $>5-12$ tahun (18,60\%\%) dibandingkan laki-laki. Persentase konsumsi air kemasan lebih tinggi pada kelompok kontrol $(79,10 \%)$ dibandingkan kasus $(55,80 \%)$. Terdapat hubungan bermakna antara diare dengan lingkungan dan higienitas (OR=5,247; 95\% IK: 2,050-13,590; $p=0,000$;), perilaku mencuci tangan ( $O R=4,483 ; 95 \%$ IK: $1,732-$ $12,132 ; p=0,002)$, serta makanan (0R=3,529; $95 \%$ IK: 1,445-8,619; $\mathrm{p}=0,005 ;$ ). Akan tetapi tidak terdapat hubungan bermakna antara diare dengan sumber air minum $(O R=2,246 ; 95 \%$ IK: 0,917-5,504; $\mathrm{p}=0,074 ;$ ).

Kesimpulan: Variabel lingkungan dan higienitas, perilaku mencuci tangan, maupun makanan memiliki hubungan yang bermakna dengan kejadian diare pada anak usia 1-12 tahun di wilayah kerja Puskesmas II Denpasar Barat, Bali, Indonesia. 


\section{PENDAHULUAN}

Diare didefinisikan sebagai buang air besar dengan feses yang tidak berbentuk (unformed stools) atau cair dengan frekwensi lebih dari tiga kali dalam 24 jam dengan atau tanpa lendir, darah atau pus. ${ }^{1}$ Bila diare berlangsung kurang dari dua minggu disebut sebagai diare akut, bila diare berlangsung 2 minggu atau lebih, maka digolongkan pada diare kronik. ${ }^{2}$ Gejala ikutan dapat berupa mual, muntah, nyeri abdominal, mulas, tenesmus, demam, dan tanda-tanda dehidrasi. ${ }^{2}$ Pada penderita diare, zat-zat makanan yang masih diperlukan tubuh terbuang bersamaan dengan terjadinya dehidrasi. ${ }^{3}$ Apabila anak balita sering mengalami diare, pertumbuhannya tidak dapat berlangsung secara optimal. Etiologi diare yaitu Rotavirus, Escherichia coli, Shigella, Campylobacter jejuni, Vibrio cholera, Entamoeba histolytica, Giardia lambia, dan Salmonella sp. ${ }^{4}$ Diare bisa dipengaruhi oleh berbagai hal seperti (a) pemberian ASI (air susu ibu), (b) pemberian makanan pendamping, (c) penggunaan air bersih, (d) kebiasaan mencuci tangan dengan sabun sebelum makan, menyiapkan makanan dan sesudah buang air besar dan (e) penggunaan jamban untuk buang air besar. ${ }^{5}$

Diare merupakan salah satu masalah kesehatan masyarakat, karena angka kesakitan masih tinggi dan berpotensi menyebabkan kematian, terutama apabila penanganan terlambat dilakukan. ${ }^{6}$ Studi sebelumnya menyebutkan bahwa WHO memperkirakan 4 miliyar kasus terjadi di dunia dan 2,2 juta diantaranya meninggal, sebagian anak-anak di bawah umur 5 tahun. ${ }^{7}$ Sebuah studi yang dilakukan dari tahun 2000-2010 di Indonesia terlihat kecenderungan angka inside diare meningkat seiring dengan buruknya sanitasi dan kebersihan air. ${ }^{8}$ Berdasarkan Studi Mortalitas dan Riset Kesehatan Dasar dari tahun ke tahun diketahui bahwa diare masih menjadi penyebab utama kematian balita di Indonesia akibat rotavirus dan diakibatkan tatalaksana yang tidak tepat baik di rumah maupun di sarana kesehatan. ${ }^{9}$

Di Kota Denpasar diare masuk dalam pola 10 besar penyakit yang dijumpai di Puskesmas. ${ }^{10}$ Menurut data Dinas Kesehatan Provinsi Bali tahun 2015 ditemukan kasus diare sebanyak 18.845 orang di Kota Denpasar. ${ }^{10}$ Mengetahui faktor risiko diare pada anak, diharapkan dapat dipakai pegangan dalam pencegahan dan edukasi yang memadai untuk mencegah meningkatnya angka mortalitas akibat diare. Pemilihan lokasi yaitu di Kecamatan Denpasar Barat dikarenakan jumlah kejadian diare yang masih tinggi. Tercatat pada tahun $2014 \mathrm{di}$ Kecamatan Denpasar Barat penderita diare sebanyak 6.280 orang. $^{10}$
Berdasarkan berbagai pemaparan di atas, penelitian ini bertujuan untuk mengetahui faktor-faktor risiko diare pada anak usia 1-12 tahun di wilayah kerja Puskesmas II Denpasar Barat, Bali, Indonesia.

\section{METODE}

Penelitian ini menggunakan metode analitik case control untuk mengetahui faktor risiko yang paling berperan sebagai penyebab diare pada anak usia 1-12 tahun di Puskesmas II Denpasar Barat. Kelompok kasus yaitu anak usia 1-12 tahun yang didiagnosa diare oleh dokter yang bertugas di Puskesmas II Denpasar Barat. Kelompok kontrol yaitu anak usia 1-12 tahun yang didiagnosa bukan diare oleh dokter Puskesmas II Denpasar Barat pada bulan yang sama.

Populasi target pada penelitian ini adalah anakanak penderita diare di Denpasar Barat, sedangkan populasi terjangkau adalah anak-anak usia 1-12 tahun yang menderita diare di Puskesmas II Denpasar Barat periode bulan September sampai November 2017. Subjek penelitian terdiri dari 2 kelompok dimana masing-masing kelompok jumlahnya sama, yaitu 43 subjek penelitian untuk tiap kelompok anak menderita diare dan anak yang tidak menderita diare, sehingga total subjek penelitian sebesar 86. Ciri-ciri sampel pada penelitian ini adalah anak-anak usia 1-12 tahun yang menderita diare dan tidak diare di Puskesmas II Denpasar Barat selama bulan September hingga November 2017. Responden penelitian adalah orang tua atau pendamping anak yang menderita diare dan tidak diare di Puskesmas II Denpasar Barat. Sampel dipilih dengan menggunakan consecutive sampling, semua subyek yang datang berurutan dan memenuhi kriteria pemilihan dimasukkan dalam penelitian sampai jumlah subjek yang diperlukan terpenuhi.

Variabel bebas dalam penelitian ini adalah faktor risiko terjadinya diare meliputi faktor lingkungan, sumber air minum, perilaku cuci tangan dan makanan. Variabel tergantung pada penelitian ini adalah penderita diare.

Adapun instrumen yang digunakan dalam penelitian ini adalah kuesioner dan observasi yang digunakan untuk memperoleh data umur, jenis kelamin, keadaan lingkungan dan higienitas, sumber air minum, perilaku mencuci tangan, dan pemanfaatan serta penyimpanan makanan. Faktor lingkungan dan higienitas terdiri dari 11 pertanyaan, faktor sumber air bersih menggunakan 7 pertanyaan, dan faktor makanan terdiri 5 pertanyaan. Ketiga faktor risiko tersebut dinilai menggunakan skala Gutman. Faktor perilaku mencuci tangan terdiri dari 7 pertanyaan dan dinilai menggunakan skala Linkert. 
Proses pengumpulan data dilakukan dengan data primer yang dikumpulkan melalui wawancara langsung kepada orang tua atau yang mengantarkan anak usia 1-12 tahun yang menderita diare dan tidak diare ke puskesmas menggunakan kuesioner yang sudah dipersiapkan. Data sekunder yang didapat dari Puskesmas untuk mencari sampel yang berobat di Puskesmas II Denpasar Barat.

Analisis data dilakukan dengan sistem komputerisasi menggunakan piranti lunak SPSS versi 20 untuk Windows. Data faktor risiko penderita diare dikumpulkan dan disajikan dalam bentuk kategorikal. Analisis dalam penelitian ini dilakukan dengan uji chi-square untuk mendapatkan faktor risiko yang berpengaruh terhadap kejadian diare dan mencari nilai rasio odds atau odds ratio (OR).

\section{HASIL}

Berdasarkan data pada Tabel 1, umur dan jenis kelamin sampel baik kasus maupun kontrol disetarakan. Kejadian diare paling banyak mengenai anak balita terutama dengan jenis kelamin perempuan sebesar 37,2\%. Laki-laki pada usia di atas 5 tahun merupakan yang paling jarang terkena diare dimana persentasenya sebesar $11,6 \%$ (Tabel 1). Penggunaan air kemasan terbanyak terjadi pada kelompok kasus yakni sebesar 79,1\% sedangkan penggunaan air yang dimasak paling banyak digunakan oleh kelompok kasus sebesar 44,2\% (Tabel 1).

Hubungan berbagai variabel terhadap kejadian diare pada anak usia 1-12 tahun di wilayah kerja Puskesmas II Denpasar Barat, Bali, Indonesia ditunjukkan pada Tabel 2. Penelitian ini menunjukkan bahwa sebagian besar kasus diare terjadi pada lingkungan dan higienitas (58,10\%), kebiasaan mencuci tangan $(81,40 \%)$, dan makanan $(60,50 \%)$ yang buruk (Tabel 2). Berdasarkan analisis resiko, terdapat peningkatan hubungan yang bermakna antara lingkungan dan higienitas (OR: 5,247; 95\% IK: 2,050-13,590; $\mathrm{p}=0.000$ ), kebiasaan mencuci

Tabel 1 Karakteristik Dasar Responden Penelitian

\begin{tabular}{lcc}
\hline Karakteristik & Kasus $\mathbf{( N = 4 3 )}$ & Kontrol $\mathbf{( N = 4 3 )}$ \\
\hline Usia, $\mathbf{n}(\%)$ & $30(69,76)$ & \\
1-5 Tahun & $14(32,60)$ & $30(69,76)$ \\
Laki-Laki & $16(37,20)$ & $14(32,60)$ \\
Perempuan & $13(30,24)$ & $16(37,20)$ \\
$>5-12$ Tahun & $5(11,60)$ & $13(30,24)$ \\
Laki-Laki & $8(18,60)$ & $5(11,60)$ \\
Perempuan & & $8(18,60)$ \\
Air Konsumsi, n (\%) & $24(55,80)$ & $34(79,10)$ \\
Air kemasan & $19(44,20)$ & $9(20,90)$ \\
Air yang dimasak &
\end{tabular}

Tabel 2 Hubungan Berbagai Variabel terhadap Kejadian Diare pada Anak

\begin{tabular}{|c|c|c|c|c|c|}
\hline Variabel & $\begin{array}{c}\text { Kasus } \\
\text { n (\%) }\end{array}$ & $\begin{array}{c}\text { Kontrol } \\
\text { n (\%) }\end{array}$ & OR & $95 \%$ IK & $\mathbf{P}$ \\
\hline \multicolumn{6}{|c|}{ Lingkungan dan Hiegenitas, n (\%) } \\
\hline Baik & $18(41,90)$ & $34(79,10)$ & 5,247 & $2,050-13,590$ & 0,000 \\
\hline Buruk & $25(58,10)$ & $9(20,90)$ & & & \\
\hline \multicolumn{6}{|c|}{ Sumber air minum, n (\%) } \\
\hline Baik & $23(53,50)$ & $31(72,10)$ & 2,246 & $0,917-5,504$ & 0,074 \\
\hline Buruk & $20(46,50)$ & $12(27,90)$ & & & \\
\hline \multicolumn{6}{|c|}{ Kebiasaan mencuci tangan, $n(\%)$} \\
\hline Baik & $8(18,60)$ & $22(51,20)$ & 4,483 & $1,732-12,132$ & 0,002 \\
\hline Buruk & $35(81,40)$ & $21(48,80)$ & & & \\
\hline \multicolumn{6}{|c|}{ Makanan, n (\%) } \\
\hline Baik & $17(39,50)$ & $30(69,80)$ & 3,529 & $1,445-8,619$ & 0,005 \\
\hline Buruk & $26(60,50)$ & $13(30,20)$ & & & \\
\hline
\end{tabular}

IK: Interval Kepercayaan; p: analisis Chi-Square dikatakan bermakna apabila kurang dari 0,050 
tangan (OR: 4,483; 95\% IK: 1,732-12,132; $\mathrm{p}=0,002)$, maupun makanan (OR: 3,529; 95\% IK: 1,445-8,619; $\mathrm{p}=0,005)$ yang buruk terhadap kejadian diare pada anak (Tabel 2). Akan tetapi tidak terdapat peningkatan resiko yang bermakna pada variabel sumber air minum terhadap kejadian diare pada anak (OR: 2,246; 95\% IK: 0,917-5,504; $\mathrm{p}=0,074$ ) (Tabel 2).

\section{PEMBAHASAN}

Penelitian menunjukkan bahwa pada kelompok kasus sebesar $41.90 \%$ memiliki lingkungan dan higienitas yang baik dan 58,10\% memiliki lingkungan dan higienitas buruk. Hasil uji statistik menunjukkan adanya hubungan bermakna antara lingkungan dan higienitas dengan kejadian diare. Hasil ini sejalan dengan penelitian yang dilakukan oleh Tambuwun F et al., mengenai hubungan sanitasi lingkungan dengan kejadian diare pada anak usia sekolah yang mengatakan bahwa sanitasi lingkungan berhubungan bermakna terhadap kejadian diare dan lingkungan serta sanitasi yang buruk berisiko 10,8 kali lebih besar menderita diare dibandingkan dengan sanitasi lingkungan yang baik. ${ }^{11}$ Penelitian lain yang juga sejalan adalah Tangka JW et al., mengenai faktor-faktor yang berhubungan dengan kejadian diare pada anak balita, maupun studi oleh Anjela R di Kelurahan Limau Manis Selatan, yang menunjukkan faktor higienitas memiliki hubungan bermakna secara statistik dengan kejadian diare $(\mathrm{p}<0,05) .{ }^{12,13}$

Menurut Sinthamurniwaty (2006) sanitasi lingkungan yang tidak saniter akan memperpendek rantai penularan diare. ${ }^{14}$ Pendapat dari Dini F et al., mengenai pengelolaan lingkungan dan higienitas yang tidak baik menimbulkan penyakit yang multi kompleks. ${ }^{15}$ Penyebaran penyakit yang bersumber dari feses dapat melalui berbagai macam jalan dan cara baik melalui air, tangan, lalat maupun tanah yang terkontaminasi. Kurangnya pengelolaan lingkungan akan mempercepat penyebaran diare. ${ }^{15}$

Hasil penelitian ini menunjukkan bahwa pada kelompok kasus memiliki 46,50\% dengan kategori buruk sedangkan hanya 27,90\% kelompok kontrol yang memiliki kualitas air yang buruk meskipun tidak bermakna secara statistik. Hasil penelitian ini sejalan dengan penelitian oleh Anjela $R$ tentang faktor-faktor yang berhubungan dengan kejadian diare di Kelurahan Limau Manis Selatan dan penelitian Aini $\mathrm{N}$ et al., mengenai hubungan kualitas air minum dengan kejadian diare. ${ }^{13,16}$ Studi sebelumnya menyatakan bahwa tidak ada hubungan bermakna antara sumber air minum dengan kejadian diare $(\mathrm{p}>0,05) .{ }^{12,16}$ Terdapat pula beberapa penelitian yang tidak sejalan dengan hasil yang didapat pada penelitian ini yaitu penelitian oleh Putra IGBGM tentang faktor-faktor risiko terjadinya diare akut dan Wulandari AP mengenai hubungan antara faktor lingkungan dan faktor sosiodemografi dengan kejadian diare, penelitian tersebut mengungkapkan adanya hubungan bermakna antara sarana air bersih dengan kejadian diare $(\mathrm{p}<0,05){ }^{17,18}$

Faktor sumber air minum tidak memiliki hubungan bermakna dengan kejadian diare pada anak di wilayah kerja Puskesmas II Denpasar Barat. Hal ini terjadi karena mereka menggunakan air minum dalam kemasan maupun telah melakukan pengolahan air sederhana yaitu dengan cara dimasak hingga mendidih. Menurut studi yang dilakukan oleh Hidayanti disinfeksi dan filtrasi juga dapat menurunkan risiko diare. ${ }^{19}$ Hasil penelitian Putra IGBGM dan Wulandari AP yang mengatakan sumber air minum memiliki hubungan bermakna dengan diare dikarenakan sebagian besar sampel mereka menngunakan air minum yang tidak diolah dengan baik. ${ }^{17,18}$

Berdasarkan hasil penelitian ini diketahui bahwa sebanyak 81,6\% kelompok kasus mencuci tangan dengan kategori buruk, berbeda halnya dengan kelompok kontrol sebanyak 48,2\% mencuci tangan dengan kategori buruk. Hasil penelitian ini memiliki hasil yang sesuai dengan penelitian yang dilakukan oleh Anjela R tentang faktor-faktor yang berhubungan dengan kejadian diare di Kelurahan Limau Manis Selatan, Evayanti NKE et al., mengenai faktor-faktor yang berhubungan dengan kejadian diare yang berobat ke BRSU Tabanan, dan Fatmawati et al., dalam penelitian tentang faktor yang memengaruhi kejadian diare pada anak menyebutkan adanya hubungan yang bermakna antara perilaku mencuci tangan terhadap kejadian diare $(\mathrm{p}<0,05) .^{13,20,21}$

Studi yang dilakukan Anjela $\mathrm{R}$ menyatakan kebiasaan yang berhubungan dengan hiegenitas perorangan yang paling penting dalam penularan mikroorganisme penyabab diare adalah mencuci tangan. ${ }^{13}$ Mencuci tangan dengan sabun, terutama sesudah membuang air besar, sesudah membersihkan tinja anak, sebelum menyiapkan/menyuapi makanan, dan sebelum makan mempunyai dampak positif dalam penurunan kejadian diare. ${ }^{13}$ Pendapat dari Cita RS kurangnya kesadaran akan kebersihan pada setiap orang di sekeliling anak akan menyebabkan mudahnya tersebar diare. ${ }^{22}$ Tangan yang mengandung kuman penyakit jika tidak dibersihkan dapat menjadi jalur masuknya kuman penyakit baik melalui mulut ataupun kontak dengan makanan serta minuman. ${ }^{22}$

Dari hasil penelitian didapatkan kelompok kasus sebesar $60,5 \%$ memilih makanan dengan kategori buruk dimana hanya 30,2\% dengan kategori buruk 
ditemukan pada kelompok kontrol. Hasil penelitian yang serupa diungkapkan oleh Sharfina $\mathrm{H}$ et al., mengenai pengaruh faktor lingkungan dan perilaku terhadap kejadian diare yang mengatakan adanya hubungan bermakna antara pengolahan, penyediaan dan penyajian makanan terhadap kejadian diare. ${ }^{23}$ Sedangkan Fatmawati et al., mengenai faktor risiko yang memengaruhi kejadian diare pada anak juga mengemukakan hasil yang sama yaitu adanya hubungan bermakna antara diare dan makanan. ${ }^{21}$

Studi yang dilakukan oleh Hidayanti R menyatakan higienitas dan sanitasi makanan penting dilakukan untuk mencegah terjadinya kontaminasi yang dapat menimbulkan gangguan kesehatan. ${ }^{19}$ Menurut Hernanda AP et al., pencemaran di rumah dapat terjadi apabila tempat penyimpanan makanan tidak tertutup dengan baik. ${ }^{24}$ Pemilihan bahan makanan yang digunakan pada pembuatan makanan oleh produsen biasanya kurang terjamin mutunya selain itu cara penyimpanan makanan tidak dilakukan dengan benar sehingga mengakibatkan adanya kontaminasi oleh mikroorganisme patogen. ${ }^{24}$ Hal ini dimaksudkan untuk menjaga kebersihan dan tingkat higienitas makanan yang akan dikonsumsi dimana studi sebelumnya oleh mengatakan makanan yang kurang bersih serta tidak higienis akan meningkatkan kejadian diare sebanyak $52 \% .^{21,25}$

\section{SIMPULAN}

Terdapat hubungan bermakna antara faktor risiko meliputi lingkungan dan hiegenitas, perilaku mencuci tangan dan makanan dengan kejadian diare pada anak usia 1-12 tahun di Puskesmas II Denpasar Barat. Untuk faktor risiko sumber air tidak memiliki hubungan yang bermakna namun tetap kelompok kasus memiliki risiko 2 kali lebih besar menderita diare dibandingkan kelompok kontrol. Saran untuk puskesmas diharapkan dapat memberikan penyuluhan mengenai diare, terutama tentang pentingnya kebersihan lingkungan maupun makanan dan minuman serta menjaga higiene pribadi.

\section{KONFLIK KEPENTINGAN}

Tidak terdapat konflik kepentingan dalam penulisan laporan penelitian ini.

\section{ETIKA PENELITIAN}

Penelitian ini telah mendapatkan persetujuan etik oleh Komisi Etik Fakultas Kedokteran Universitas Udayana, Bali, Indonesia sebelum studi dilakukan.

\section{PENDANAAN}

Penulis bertanggung jawab secara penuh terhadap pendanaan dari penelitian tanpa melibatkan pihak sponsor, beasiswa, ataupun sumber pendanaan lainnya.

\section{KONTRIBUSI PENULIS}

Kontribusi yang dilakukan oleh masing-masing penulis bersifat setara baik dari tahap penyusunan kerangka konsep, pengumpulan data, analisis data penelitian, hingga interpretasi data penelitian dalam bentuk publikasi ilmiah.

\section{UCAPAN TERIMA KASIH}

Terima kasih peneliti ucapkan kepada keluarga besar Puskesmas II Denpasar Barat yang telah membantu peneliti dalam proses pengumpulan data. Terima kasih juga peneliti sampaikan kepada dr. I Nengah Kapti, Sp.ParK serta pihak lain yang berperan sejak awal hingga akhir penelitian.

\section{DAFTAR PUSTAKA}

1. Barr W, Smith A. Acute diarrhea. Am Fam Physician. 2014;89(3):180-189.

2. Schiller LR, Pardi DS, Sellin JH. Chronic Diarrhea: Diagnosis and Management. Clin Gastroenterol Hepatol. 2017;15(2):182-193.e3.

3. Meier R, Burri E, Steuerwald M. The role of nutrition in diarrhoea syndromes. Curr Opin Clin Nutr Metab Care. 2003;6(5):563-567.

4. Operario DJ, Houpt E. Defining the causes of diarrhea: novel approaches. Curr Opin Infect Dis. 2011;24(5):464-471.

5. Ganguly E, Sharma PK, Bunker CH. Prevalence and risk factors of diarrhea morbidity among under-five children in India: A systematic review and meta-analysis. Indian J Child Health (Bhopal). 2015;2(4):152-160.

6. GBD 2016 Diarrhoeal Disease Collaborators. Estimates of the global, regional, and national morbidity, mortality, and aetiologies of diarrhoea in 195 countries: a systematic analysis for the Global Burden of Disease Study 2016. Lancet Infect Dis. 2018;18(11):1211-1228. doi: 10.1016/ S1473-3099(18)30362-1

7. Adisasmito W. Faktor risiko diare pada bayi dan balita di indonesia: Systematic review penelitian akademik bidang kesehatan masyarakat. Makara Kesehatan. 2007;11(1):1-10.

8. Komarulzaman A, Smits J, de Jong E. Clean water, sanitation and diarrhoea in Indonesia: Effects of household and community factors. Glob Public Health. 2017;12(9):1141-1155.

9. Soenarto Y, Aman AT, Bakri A, Waluya H, Firmansyah A, Kadim M, et al. Burden of severe rotavirus diarrhea in indonesia. J Infect Dis. 2009;200 Suppl 1:S188-S194.

10. Dinas Kesehatan Kota Denpasar. Profil kesehatan Kota Denpasar Tahun 2014-2015. 2014: p. 26-27.

11. Tambuwun F, Ismanto AY, Silolonga W. Hubungan sanitasi lingkungan dengan kejadian diare pada anak uisa sekolah di wilayah kerja Puskesmas Bahu Manado. e-Journal Keperawatan (e-KP). 2015;3(2):1-8.

12. Tangka JW, Alamri R, Laoh JM. Faktor-faktor yang berhubungan dengan kejadian diare pada anak balita di Puskesmas Bintauna Kabupaten Bolaang Mongondow Utara. Juiperdo. 2014;3(2);10-18. 
13. Anjela R. Faktor-faktor yang berhubungan dengan kejadian diare pada balita di Kelurahan Limau Manis Selatan Wilayah Kerja Puskesmas Pauh Tahun 2015 [Karya Tulis Ilmiah]. Padang: Poltekes Kemenkes Padang. 2015.

14. Sinthamurniwaty. Faktor-faktor risiko kejadian diare akut pada balita [Tesis]. Semarang: Universitas Diponegoro. 2006.

15. Dini F, Machmud R, Rasyid S. Hubungan faktor lingkungan dengan kejadian diare balita di Wilayah Kerja Puskesmas Kambang Kecamatan Lengayang Kabupaten Pesisir Selatan Tahun 2013. Jurnal Kesehatan Andalas. 2015;4(2):453-461.

16. Aini N, Raharjo M, Budiyono. Hubungan kualitas air minum dengan kejadian diare pada balita di wilayah kerja Puskesmas Banyuasin Kecamatan Loano Kabupaten Purworejo. Jurnal Kesehatan Masyarakat (e-Journal). 2016;4(1):399-406.

17. Putra IGBGM. Faktor-faktor risiko terjadinya diare akut pada balita di Desa Tegallalang pada Bulan Januari sampai Juli tahun 2014. E-Jurnal Medika Udayana. 2015;4(5):1-9.

18. Wulandari AP. Hubungan antara faktor lingkungan dan faktor sosiodemografi dengan kejadian diare pada balita di Desa Blimbing Kecamatan Sambirejo Kabupaten Sragen Tahun 2009 [Skripsi]. Surakarta: Universitas Muhammadiyah Surakarta. 2009.

19. Hidayanti R. Faktor risiko diare di Kecamatan Cisarua, Cigudeg dan Megamendung Kabupaten Bogor Tahun 2012 [Skripsi]. Depok: Universitas Indonesia. 2012.

20. Evayanti NKE, Purna IN, Aryana IK. Faktor-faktor yang berhubungan dengan kejadian diare pada balita yang berobat ke Badan Rumah Sakit Umum Tabanan. Jurnal Kesehatan Lingkungan. 2014;4(2):134-139.
21. Fatmawati, Arbianingsih, Musdalifah. Faktor yang mempengaruhi kejadian diare anak usia 3-6 tahun di TK Raudhatul Athfal Alauddin Makassar. Journal of Islamic nursing. 2016;1(1):21-32.

22. Cita RS. Hubungan sarana sanitasi air bersih dan perilaku ibu terhadap kejadian diare pada balita usia 10-59 bulan di wilayah Puskesmas Keranggan Kecamatan Setu Kota Tanggerang Selatan tahun 2013 [Skripsi]. Jakarta (Indonesia): Universitas Islam Negeri Syarif Hidayatullah Jakarta. 2013.

23. Sharfina H, Fakhriadi R, Rosadi D. Pengaruh faktor lingkungan dan perilaku terhadap kejadian diare pada balita di wilayah kerja Puskesmas Sungai Tabuk Kabupaten Banjar. Jurnal Publikasi Kesehatan Masyarakat Indonesia. 2016;3(3):88-93.

24. Hernanda AP, Djallalluddin, Noor MS. Hubungan perilaku jajan dengan kejadian diare pada anak sekolah dasar di Kel. Cempaka Kec. Cempaka Kota Banjarbaru. Jurnal Berkala Kedokteran. 2013;9(1):93-100.

25. Ani LS, Suwiyoga K. Traveler's Diarrhea Risk Factors on Foreign Tourists in Denpasar Bali-Indonesia May and August 2013. Bali Medical Journal. 2016;5(1):152-156.

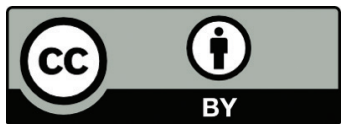

This work is licensed under a Creative Commons Attribution 